\title{
Situational crime prevention and Public Safety Canada's crime-prevention programme
}

\author{
Tarah Hodgkinson ${ }^{1} \cdot{\text { Graham } \text { Farrell }^{2}}^{2}$
}

(C) Macmillan Publishers Ltd 2017

\begin{abstract}
This study examines the work undertaken by Canada's National Crime Prevention Centre (NCPC) under the auspices of the Public Safety Canada. NCPC operates with a social development approach to preventing crime, focussing largely on small pilot projects that work with at-risk youth. We suggest that this is a rather narrow definition of crime prevention and that it may not necessarily be an optimal strategy for all crime preventions in Canada. In particular, many international crime and safety organizations suggest the need for integrated approaches in crime prevention. In addition, there is an array of evidence-based situational crime prevention (SCP) strategies from which Canada might benefit. SCP has a history of success in designing out a wide range of crimes from credit card fraud to car theft and burglary. It is proposed that, at minimum, a more inclusive crime-prevention programme that incorporates SCP would produce a significant net benefit to the safety of Canadians.
\end{abstract}

Keywords Situational crime prevention - Canada - Public policy · Crime prevention - National Crime Prevention Centre

\section{Introduction}

Preventing crime is more cost effective and beneficial for Canadians than reactionary methods, such as increasing the number of police or implementing harsher punishments (Waller 2008). There is currently a lot of momentum around the topic of crime prevention in Canada (CMNCP 2016). For example, the province

Tarah Hodgkinson

thodgkin@sfu.ca

1 School of Criminology, Simon Fraser University, 8888 University Drive, Burnaby, BC V5A 1S6, Canada

2 School of Law, University of Leeds, Leeds LS2 9JT, UK 
of Ontario has developed a framework for community safety and well-being. This framework is a holistic model, with a particular focus on community engagement and direct guidance for practitioners (Russell and Taylor 2014). Further, the Canadian Municipal Network on Crime Prevention (CMNCP) is bringing together municipalities from across the country to focus on an integrated approach that fosters municipal leadership on crime-prevention initiatives (2016). Cities within the network have developed their own partnerships around integrated crime prevention, such as The Regina Intersectoral Partnership (TRIP), City of Saskatoon Neighbourhood Safety and SafeGrowth ${ }^{\circledR}$ and The City of Surrey Public Safety Strategy (CMNCP 2016). These initiatives are focussed on long-term strategies that bring together the knowledge on best practices in crime prevention and use integrated frameworks for implementation. However, at the national level, there is much work that still needs to be done.

Canada has only started investing in crime prevention at the national level in the last twenty years (Public Safety Canada 2013). The main funding for crime prevention in Canada is supplied by Public Safety Canada's Crime Prevention Program (CPP) which supports all of the National Crime Prevention Centre (NCPC) affairs. The NCPC's approach to crime prevention is based on crime prevention through social development (CPSD) (Hastings 2005). While social development is important for the well-being of Canadians, it is only one approach to crime prevention and does not address all types of crime (Knepper 2009). Canadian criminologists have discussed the benefits of integrated crime-prevention frameworks that include situational crime prevention (SCP) (Waller 2013; Sacco and Kennedy 2011). Internationally, several authors and organizations have also demonstrated support for combining both SCP and CPSD (see, for example: Karmen 2000; World Health Organization 2010: United Nations Office on Drugs and Crime 2010, Vanderschueren 1998). However, in the case for SCP, an additional approach for NCPC to consider has not been clearly made. SCP techniques are known to reduce crime opportunities and address particular types of crime that may be emerging (Clarke 1997; Brantingham et al. 2005; Knepper 2009; Linden and Chaturvedi 2005). Here, SCP is an encompassing term that includes improving or expanding key components of security that reduce crimes such as auto theft and burglary. Hence, the present study proposes that the NCPC would benefit from complementing its current framework with support for SCP programmes to establish a more integrated approach to crime prevention in Canada.

\section{Crime in Canada}

It is important to understand crime in Canada, before discussing prevention and reduction. Canada is a geographically and socially diverse country. It is well known that crime occurs in particular areas and not others. Thus, one would expect that crime rates differ across the country. Typically, violent and property crime rates are higher in Western Canada than those in eastern Canada, with the highest crime rates in Canada's northern territories (Andresen 2009; Statistics Canada 2013). This finding is supported by the crime severity index, a recent development that weights 
crimes that are legally more serious to create a crime rate that more accurately reflects the rates of serious crime in an area (Wallace et al. 2009). Violent and property crime rates are also higher in urban areas than rural areas; however, recently this has been identified as possibly a product of lack of reporting (Statistics Canada 2013; Carleton et al. 2014). Within cities, crime concentrates in certain areas and particular types of crime, like auto theft, also cluster spatially (Curman et al. 2015; Andresen and Malleson 2011; Hodgkinson et al. 2016). Furthermore, some communities experience higher crime rates than others. For example, Canada has a large First Nations population. First Nations communities are often characterized by poverty, a lack of resources and other social problems (Government of Canada 2013). As such, these communities often experience higher crime rates than other Canadian communities, and First Nations persons can be twice as likely to experience violent victimization, compared with non-First Nations Canadians (Government of Canada 2015).

The Uniform Crime Report (UCR) and the International Crime Victims Survey (ICVS) have shown that crime in Canada has been declining since the 1990s as part of an international crime drop (Statistics Canada 2013; van Dijk et al. 2012; Ouimet 2002; Farrell and Brantingham 2013). This downward trend remains consistent despite a slight increase in crime rates in 2015, the first increase since 2003 (Allen 2016) In contrast, until the most recent survey year (2014), the Canadian General Social Survey (GSS)'s victimization survey showed stable rates of victimization (CBC News 2010; Casavant 2010; Perreault 2015). The Canadian General Social Survey is often heralded as being methodologically superior to other tools for capturing crime rates, as it addresses issues with reporting to police (Casavant 2010). However, Farrell and Brantingham (2013) demonstrate that even when UCR data are inflated to account for GSS trends in underreporting to the police, the crime rate is still declining. Furthermore, the ICVS demonstrates similar trends between victimization surveys in the United States and their UCR rates (Farrell and Brantingham 2013).

Despite a declining trend in both violent and property crime rates, particular types of crimes are increasing in Canada and internationally, such as mobile theft, identity theft and internet fraud (Mailley et al. 2008; Symantec 2013). Two important questions emerge: why has crime declined in Canada and how will Canada address new types of crime in the twenty-first century? Several researchers and theorists have offered explanations for the decline in crime. These explanations include increased imprisonment, policing, youth intervention, tougher laws that result in harsher punishments, and even access of abortion (Levitt 2004). It is reasonable to assume that some, if not all of these explanations are plausible in the Canadian and North American context. However, they fail to explain the simultaneous international decline in crime.

An alternative hypothesis is that improvements in security technology could be the driving factor preventing much property crime and in turn access to some violent crimes. The security hypothesis claims that security improvements such as improved locks and electronic immobilizers for cars have reduced crime opportunities by increasing effort (Farrell et al. 2011). When compared against 16 alternative explanations, the security hypothesis appears to fulfil the requirements of 
a set of criteria identified as necessary to explain the international nature of the decline in crime (Farrell et al. 2014). The security hypothesis claims that situational crime-prevention techniques have addressed particular types of crime in specific way. Thus, this hypothesis can help to not only understand the decline in crime in Canada, but also the possibilities for situational crime prevention to address emerging and increasing crime types.

\section{Situational crime prevention}

Situational crime prevention (SCP) can be defined as measures taken to reduce crime opportunities (Clarke 1997). SCP addresses the particular nature of the crime itself, the environmental factors that allow for the commission of the crime, and the risks and rewards associated with said crime (Clarke 1997). SCP refocuses crime-prevention tactics from the offender to the particular situation with which the potential offender is faced (Tilley 2009). Situational crime prevention is crime specific. It does not address categories of crime such as theft or assault, but goes further to respond to specific types and modus operandi of those offences (Clarke 1997). For example, a particular situation that could allow for auto theft in a large metropolitan area could consist of the car having poor locks, no security alarm, and limited lighting in the parking lot, making it easy to conceal a break-in, few people frequenting the parking lot that could act as a form of natural surveillance, several entry and exit points allowing for easy escape, and the proximity of the car to potential offenders which increases the likelihood that the car will be stolen. SCP is thus useful for addressing the multitude of factors that contribute to crime opportunity.

The two main theories related to SCP are routine activities theory and rational choice theory. Routine activities theory posits that in order for a criminal event to occur, three components must come together in time and space: a motivated offender, a suitable target and lack of capable guardianship (Cohen and Felson 1979). After the Second World War, living conditions across North America had improved substantially; the economy was strong and socio-economic conditions were improving. Despite this improvement, crime rates rose (Cohen and Felson 1979). Routine activities theory emerged as an explanation for this seemingly incongruent situation. The rise in access to durable and portable goods that could be sold easily and anonymously, a move towards independent living; women were also entering the workforce rather than staying home, and individuals were spending more time in social activities away from the home (Cohen and Felson 1979). Thus, an increase in suitable targets (the durable and portable goods), combined with a lack of capable guardianship (change in lifestyles away from the home) led to an increase in crime. Routine activities theory informs situational crime prevention by assuming a potential offender and instead analysing how one can change the situation in order to reduce the opportunities for crime (Cohen and Felson 1979).

According to rational choice theory, all actors make rational decisions, based on a cost and benefit analysis (Clarke and Cornish 1985). This does not mean that all actors are equally rational. Offenders can operate under limited or bounded rationality, in which they do not consider all the risks and benefits of their actions 
(Clarke and Cornish 1985). However, rational choice theory posits that if the risks of a particular action increase, or the benefits reduce, some crimes can be prevented (Clarke and Cornish 1985). Rational choice theory posits that offenders and nonoffenders are rarely two distinct groups of people and rather situations are more or less criminogenic.

Cornish and Clarke (2003) identified a set of SCP techniques. These include prevention approaches that increase effort and/or risk of crime commission, reduce rewards, and remove excuses and/or provocations. In order to increase effort and/or risk, prevention specialists can make the crime harder to execute, through physical or social barriers. To reduce rewards, practitioners can alter the visibility of possible targets, so benefits remain unknown. To reduce provocations, emotional triggers can be limited. Finally, rules can be redefined to be more comprehensive, thus removing ignorance as an excuse (Cornish and Clarke 2003). These strategies will be discussed further with examples, under implementation.

Situational crime prevention approaches are already common place in several other countries internationally. The United Nations Office on Drugs and Crime (UNODC) includes SCP in its methods through which countries should prevent crime (UNODC 2002, 2010). Crime prevention through environmental design is required in urban planning in Australia. This includes a crime reduction checklist for urban planners (Knepper 2012). Denmark, Sweden, Finland and Norway have all included SCP in their national strategy since the 1970s and 1980s (Knepper 2012). Furthermore, the Problem Oriented Policing Centre (popcentre.org) offers a website with detailed information not only on SCP, but also its long theoretical evolution and substantial success rate. Thus, while social development models are important for addressing some of the well-known risk factors of crime, SCP measures are designed to address specific crime issues. When done correctly, SCP does not lead to fortress society but can produce 'elegant security' that enhances liberties (Tilley et al. 2015).

Situational crime prevention assumes the presence of a potential offender and addresses the opportunity for a crime to occur, instead of trying to address possible criminal motivation or risk factors associated with developing criminally prone individuals. Crime opportunity theories focus on the role of a suitable target and the lack of capable guardianship. SCP offers no "silver bullets" for the problem of crime. Instead, SCP advocates for small changes to offending opportunity in crimespecific ways (Tilley 2009). Although the Canadian government has formally identified the need for situational crime prevention in the prevention literature (see Public Safety Canada 2007b), to date, it does not appear to be part of governmentsponsored practice.

\section{Overview of crime prevention in Canada}

Before discussing the issues with the current national crime-prevention framework in Canada, and the benefits of an integrated approach, we provide some of the history of the current crime-prevention programme. The origins of Public Safety 
Canada's Crime Prevention Program (CPP) date back to 1994 . $^{1}$ The programme emerged largely out of social development and situational crime-prevention research (Vanderschueren 1998) and was an attempt to transition from the traditional reactive approach to crime, such as increasing police numbers or imposing harsh sentences, towards a multi-sectoral and municipal based strategy (Hastings 2005; Public Safety Canada 2007a). At the time the federal government was spending very little on prevention and any prevention efforts were underfunded and solely community based. With no consistent and formal national funding, such programmes were unable to employ well-trained personnel or to develop effective and sustainable programming (Hastings 2005). A national council, the NCPC, was then developed through federal, provincial, municipal and community-based partnerships. The council was charged with designing a holistic model for crime prevention in Canada (Public Safety Canada 2007a, 2013). Although the strategy had been formed four years earlier, the Government of Canada officially began funding crime prevention in 1998 under the National Crime Prevention Strategy (NCPS).

With NCPC responsible for NCPS and its implementation, funding for crime prevention evolved to support crime prevention through social development including education programmes and early intervention. Over the next few years, programme funding expanded and the NCPC and NCPS came under the control of Public Safety Canada (Public Safety Canada 2007a). The NCPC started to develop crime-prevention knowledge and policy, as well as funding crime-prevention programme proposals (Sansfaçon and Leonard 2012). However, the NCPC did not have direct ownership over all prevention strategies. Organizations such as the RCMP, the National Drug Strategy and the Youth Justice Initiative were just a few of several crime-prevention programmes operating separately from NCPC. While coordination between these programmes was necessary, the NCPC had no direct jurisdiction over their implementation or others (Sansfaçon and Leonard 2012).

Since 1998, the National Crime Prevention Strategy (now CPP) has gone through several changes. Three components make up the revised strategy. These include community action, partnerships and knowledge building (Public Safety Canada 2007a). Community action consists of funding community prevention initiatives. Partnerships include encouraging and developing communication between research, practice and communities. The knowledge component consists of the collection, interpretation and dissemination of knowledge surrounding effective crimeprevention approaches (Public Safety Canada 2007a). Since 2007, four main principles have led the NCPS. They continue to emphasize the importance of partnerships and knowledge of evidence-based programmes. However, there is an increased emphasis on particular groups or priorities, along with demonstrable results from rigorous evaluation (Public Safety Canada 2007a).

As of 2016, the CPP funding budget is just under fifty million dollars per year, a reduction from fifty-four million in 2013 and sixty-three million in 2008. (Public

\footnotetext{
${ }^{1}$ Crime-prevention models had already emerged at this time. For example, an early model called Tandem, started in Montreal in 1986 and focussed on break and enters. The commitment to crime prevention emerged largely out of two conferences, on in Montreal in 1989 and one in Paris, France in 1991 (CMNCP 2016).
} 
Safety Canada 2009, 2013, 2016a), The CPP traditionally centralized its funding on social development programming (Hastings 2005), funding four types of programmes: community mobilization, business action, crime-prevention partnership and crime-prevention investment (Leonard et al. 2005). The crime-prevention investment fund supported initiatives from three to five years that address the risk factors of crime. After the funding period, the programs are evaluated on results and overall effectiveness (Leonard et al. 2005). The funding is centralized on a particular assumption; inequality amongst Canadian families in their ability to provide particular resources for their children is a central cause of crime and addressing these inequalities will reduce crime (Hastings 2005). However, focus has shifted slightly from strictly social development and criminal risk factors, to address particular issues including drug-crimes, youth gangs, aboriginal communities and recidivism (Public Safety Canada 2009). While these initiatives are important for the welfare of Canadians, they only address part of the crime problem.

\section{Criticisms of the current crime-prevention strategy in Canada}

Programmes that receive funding should be evidence-based, in that a valid and reliable research methodology demonstrates their effectiveness (Public Safety Canada 2013). While much work in evidence-based crime prevention has been done elsewhere, Canadian research has generated only some information on the particulars of successful crime-prevention programmes in the country (Sansfaçon and Leonard 2012). There is a lot of research supporting crime prevention through social development, finding substantial reductions in crime over $50 \%$ or better, within five years in some cases, (for a review see Waller 2013; World Health Organization 2010; National Institute of Justice 2016). Such programmes address many well-known sociological explanations of crime such as relative poverty, residential turnover and family breakdown (Sampson and Groves 1989). Thus, this is a useful and appropriate approach for NCPC to take. However, NCPC suffers by not incorporating other evidence-based approaches, such as SCP.

In an interim evaluation of NCPC, suggestions were made to incorporate a more comprehensive approach to crime that included targeting specific crimes and using situational crime-prevention measures (Public Safety Canada 2007a). ${ }^{2}$ Public Safety Canada stated that there was "a need to ensure a balanced and targeted approach in response to priority and specific crime issues... where a balanced approach includes CPSD as well as situational crime prevention" (2007a, p. 10). Furthermore, NCPC claims that they operate from the United Nations Guidelines for the Prevention of Crime, which includes situational crime-prevention measures (Public Safety Canada 2007a). Yet, based on their funding priorities, there is little evidence that this is the case. The following comments on the current CPP strategy are intended to create discussion surrounding alternative or complementary crime-prevention models.

As mentioned, NCPC operates under a social risk factor model targeting what are referred to as 'known risk factors' of crime (Public Safety Canada 2007b).

\footnotetext{
2 This is the most recent evaluation of NCPC.
} 
However, crime prevention through social development (CPSD), as with any crimeprevention model, has empirical and theoretical limitations. For example, CPSD is a perspective that assumes improvements made to quality of life will reduce all crime. Yet improving the welfare state alone does not always demonstrate a reduction in crime or victimization rates (Knepper 2009). For example, North Americans saw crime rates soar in the late 1960s when employment and economic opportunities were better than previous and subsequent decades that experienced lower crime rates (Cohen and Felson 1979); one may argue over who benefitted from the employment and economic opportunities (a relative deprivation argument), but at the aggregate level these opportunities improved.

Furthermore, many social development programmes suffer from poor empirical evaluation and support (For review, see Welsh and Farrington 2012). Programmes created to prevent participation in youth gangs in the United States suffer from poor evaluation design that does not include a control group (Tilley 2009). British cognitive behaviour programmes addressing risk factors for criminal behaviour only reduce recidivism by a relatively small percentage (a drop from 60 to 54\% in one study). Programmes designed to treat drug addiction suffer from high rates of dropout, leading to unreliable results (Tilley 2009). While there are several examples of strong empirically supported social development programmes, such as the Perry Preschool Program, Positive Parenting Program, Fourth R, and Stop Now and Plan (SNAP) (Waller 2008; World Health Organization 2010; Centre for Addiction and Mental Health 2015; Augimeri et al. 2007), CPSD is not a panacea in crime prevention. As a consequence, focussing only on social development limits the potential impact of crime prevention.

NCPC also targets 'at-risk' youth, which refers to youth who are at risk of engaging in crime later in life (Farrington 2000). Longitudinal research demonstrates that individuals make different choices throughout life and are not submissive to their childhood experiences alone. Offending is not always persistent through the life course, so something must interfere with the criminal trajectories of youth who engage in crime (Sampson and Laub 2003). Also, the definition of 'atrisk youth' can be vague. Depending on the agency collecting data on at-risk youth or defining the parameters by which to measure risk, a number of problems can fall under the at-risk umbrella (Wotherspoon and Schissel 2001). These can include health, family detachment, school difficulties, and even boredom. Different definitions of at-risk youth have led from anywhere between 30 and $40 \%$ of Canadian youth falling under this category (Wotherspoon and Schissel 2001). CPSD indirectly targets risk factors that lead to criminal behaviour. Targeting indirect factors related to a social problem like crime is not as efficient as also using direct measures that are problem specific (Lieberson 1992). This is particularly problematic when attempting to use limited public funds to address what should be a minority of the Canadian population.

The theoretical framework for the social development model used in NCPC also does not apply to all crime types such as corporate crime or fraud, both of which appear to be burgeoning (Pearce and Tombs 1998; Tombs 2013; Competition Bureau Canada 2012). The CPSD model puts forth that offenders emerge from disadvantaged homes and socially disorganized communities (Hastings 2005). 
Social development theories do not explain why those who are in privileged positions commit crime, nor does it offer crime-prevention solutions for corporate crime or fraud (Snider 1993). As such, the social development crime-prevention model on which the NCPC operates is unable to address types of crimes that arguably do substantially more damage than street crimes (Cohen 2000).

Finally, the current NCPC model for providing funding and requiring evaluation is not particularly practical for CPSD programmes alone. The funding is usually limited to supporting small scale projects replicating strategies that have already demonstrated effectiveness. For example, the Atlantic Youth Inclusion Program is based on evidence from an English and Wales program (Public Safety Canada 2016b). This does not encourage new and promising programmes to be developed and tested in Canada. Nor does it match the sustainable funding many Canadian cities are now committing to crime prevention (CMNCP 016). NCPC also requires evaluation between three to five years of the start of the prevention programme (Leonard et al. 2005). It can take between ten to twenty years, if not a generation, for useful social development projects to run their course and demonstrate valuable results on both social welfare and crime (Waller 2008). These programmes also often require comprehensive problem evaluation and targeted intervention and prevention that can be quite expensive and beyond the means of the small grants offered by NCPC (Sherman et al. 1998; Waller 2013) Furthermore, project-based evaluations do not examine the parts of the process that lead to success, making it difficult to replicate them on a larger scale (Sansfacon and Waller 2001). The evaluation method, often used to demonstrate if further funding should be allocated, is not in line with social development or good scientific scholarship.

Clearly, there is room for growth within NCPC's current theoretical model. Homel (2005) claims that "doing something about crime early, preferably before the damage is too hard to repair or crime becomes entrenched, strikes most people as a logical approach to crime prevention." (p. 71). However, other approaches, such as SCP, have utility for the NCPC. Several types of crime are declining and yet crime policy is not changing to address these changes (Tonry 2004). Next, we discuss how SCP is a possible collaborative tool for complementing the current CPSD model.

\section{The benefits of SCP for an integrated framework}

A significant body of literature supporting situational crime prevention has evolved across the last four decades (Mayhew et al. 1976; Clarke and Cornish 1985, Clarke and Mayhew 1988; Clarke 1997; Knepper 2009; Linden and Chaturvedi 2005). The benefits of including situational crime-prevention techniques into the national strategy include crime-specificity, lowered system costs, reassignment of responsibility and the ability to adhere to evidence-based evaluation and combine with other methods and to match current best practices in crime prevention and community safety.

Recall that, despite some debate about reporting, crime rates have been dropping in Canada for over twenty years (Statistics Canada 2013). However, particular 
crimes such as mobile phone theft, identify theft and online fraud have increased, on a global scale, due to increases in availability and opportunity. Thus, crimeprevention strategies that are crime specific, rather than only attempting to address the early risk factors of individuals, would be useful in responding to new crime problems. Recall that offenders make particular choices about which items to target and who to victimize. These decisions rest on perceived benefits of the commission of crime versus the expected risks of being apprehended (Clarke and Cornish 1985). In order to address the particular crimes that are increasing, despite the general decline in crime, an approach that reduces the benefits of these crimes, while increasing risks is necessary. Thus, prevention practices should be targeting the processes through which these specific crimes are committed, with hopes to circumvent opportunities and increase risk (Cornish 1994).

Crime prevention in Canada should ideally, and in theory, reduce costs to the criminal justice system. Social development can reduce these costs, but it can take a generation to demonstrate measurable results (Waller 2008). At-risk youth arguably comprise a large portion of the youth population (Wotherspoon and Schissel 2001). Rather than attempting to focus funds for prevention simply on locating and supporting programmes for these at-risk youth, which can be very costly and difficult to implement, an approach that also reduces opportunities by managing specific criminogenic situations could be more appropriate (Clarke 1997; Linden 2007). SCP can reduce opportunity; hence potential offenders would not be tempted with the benefits of crime in the first place and in turn may not the criminal justice system. Furthermore, by reducing perceived benefits and opportunity for certain crimes, certain neighbourhoods may become less criminogenic overall.

The NCPC requires that crime prevention be evidence-based and subject to swift appraisal (Public Safety Canada 2007a). Despite previously discussed criticisms of this current funding structure, SCP lends itself well to short-term evaluation. Thus, SCP could provide short-term success in an integrated approach that also addresses long-term social development goals. Knowledge relating to situational crimeprevention measures can be fostered via randomized control trials and results that are measurable in a much shorter time period (Braga 2005). For example, a randomized control trial of situational crime-prevention techniques sought to reduce theft of expensive razor blade kits from stores (Hayes et al. 2011). The tactics employed improved the visibility of security by placing the razors in plastic casing, increased detection through audible tones designed to ring when the box opened, improved employee handling and improved stocking procedures by reducing the amount available on the store floor (Hayes et al. 2011). The stores that had implemented the situational crime-prevention techniques reduced their rate of theft by $50 \%$ when compared to the control group (Hayes et al. 2011). These results were evident in only a few short months. This example is offered by means of support for the proposition that $\mathrm{SCP}$ can be an efficient technique amenable to swift evaluation.

The NCPC is meant to be the country's leader in knowledge about crime prevention and thus should be empowering the communities of Canada to contribute to preventing crime. Situational crime prevention shifts some of the responsibility for crime prevention to local governments, police forces and even business owners (Tilley 2009). Localizing crime prevention within communities is useful as the 
community is often the most aware of the potential sources of crime opportunities, and crime issues specific to their area (Janhevich et al. 2008). When prevention initiatives are implemented in a top-down structure by outsiders, they are often not put into place properly by the ground-level practitioners, leading to implementation problems (Homel 2006). By involving local practitioners and policy makers in the development of targeted prevention for particular local crime problems, they are better equipped to guide and implement crime prevention in their community (Saville 2009). This does not mean turning crime prevention back to a piecemeal community-based effort (Hastings 2005). Nor does it mean creating sweeping national policies that do not address specific crimes and make it difficult to disentangle cause and effect for evaluation (Sansfacon and Waller 2001). Rather, it means the centralized knowledge and funding for crime prevention is used to support localized efforts. Situational crime prevention operates under this framework, providing an integrated, multi-level approach that deals with particular crime problems instead of a blanket approach to crime.

Situational crime prevention also easily blends with other approaches. These could include the early childhood interventions and mentoring already employed by NCPC. For example, in the early 2000s, Winnipeg was dealing with one of North America's highest auto-theft rates (Manitoba Justice 2009). They developed a task force to identify the root causes and mitigating issues around their auto theft problem. Most stolen cars in Winnipeg were used for youth joyriding and subsequently discarded. Thus, the recovery rate of these cars was quite high as they were not being stolen for parts or resale. The youth who stole the cars were often from single parent, low income homes. They targeted particular cars that lacked security and were easy to break into and steal (Manitoba Justice 2009). The task force combined targeted youth intervention programmes, monitoring of prolific offenders and situational crime-prevention measures, such as improved security for vehicles. Security measures included electronic immobilizers installed in over sixty thousand cars (Linden and Chaturvedi 2005). An initial decrease in auto theft was followed by a significant increase. There was not enough supervision of prolific offenders and different cars that were not subject to security upgrades were now being stolen. The improved strategy included hiring more police to supervise prolific offenders and to expand security measures to make immobilizers mandatory. After this the decline in auto theft was significant and sustained. From 2004 to 2009, auto theft rates declined by $76 \%$ and savings were estimated at about $\$ 30$ million a year. ${ }^{3}$ (Manitoba Justice 2009). Other examples of successful blended approaches include the Kirkholt Neighbourhood Watch (Farrell and Pease 2007), Operation Ceasefire (Braga et al. 2001) and SafeGrowth (Saville 2009), all of which have been designed to be context specific and combine different crime-prevention strategies.

An integrated framework could do more than simply fund small pilot projects. Rather, it could be balanced across what is known to prevent crime, provide more funding for crime prevention to the municipalities and provinces of Canada and focus on programmes that are outcome oriented with measurable targets, testing

\footnotetext{
${ }^{3}$ The total cost of the strategy in one city was around $\$ 52$ million. Interestingly, this is slightly more than the annual budget for the entire country for NCPC.
} 
new approaches in crime prevention. A national strategy that incorporates the evidence-based situational model would, it is proposed, enhance the effective use of public funds for preventing crime in Canada and match the best practices for crime prevention from key international organizations, such as the World Health Organization (WHO) and the United Nations Office on Drugs and Crime (UNODC). Thus, by addressing a particular type of prevalent crime, reducing opportunity to commit that specific crime and including social measures such as youth mentorship, crime can be reduced. Clearly, there are many benefits of SCP which should be considered when planning and funding crime prevention in Canada.

\section{How SCP can be implemented}

Proper implementation is imperative for the success of any crime-prevention programme. Crime-prevention strategies, in general, suffer from poor implementation as a result of poor theory, lack of proper problem identification, poor use of measures or not putting them in place at all, or other measures being implemented instead of those that were intended (Tilley 2009). If the NCPC is to incorporate situational crime prevention into the national strategy, it will have to do so carefully. For NCPC, SCP is an entirely new way of approaching crime prevention. However, if NCPC succeeds in incorporating SCP, the strategies ought to be a cost-effective and efficient way of reducing specific crimes. The follow provides some examples of how to possibly implement SCP in Canada.

Because SCP is underpinned by the notion of quasi-rational offenders, it is useful to think how particular SCP measures can address the weighing of risk and reward. To increase the effort for car theft, for example, one could install ignition immobilizers, thus making it more difficult to steal (Linden and Chaturvedi 2005). To increase risk, one could improve measures of guardianship such as parking lot lighting, locked garages or parking lot security guards. These measures can increase the risk of observation. To reduce rewards, one could install tracking devices on the cars that make them easier to locate when stolen. Removing excuses involves making the law quite obvious. In the case of auto theft, cars are often stolen as a form of transportation (Copes 2003). Improved public transportation could remove this excuse. Finally, to reduce provocations one must address the situational triggers of a particular crime (Cornish and Clarke 2003). This is more common in emotionally driven inter-person crimes, such as staggering pub closing times to avoid emptying several intoxicated people onto the street at the same time. While not every SCP strategy is necessary for every type of crime, simply addressing one area can have a major impact on the crime rate.

Property crime is the most commonly recorded offence (Lester 2001). Improvements have been made conceptualizing property crime through situational measures. For example, in 1999, Clarke introduced the concept of "CRAVED" items. These items or products are "hot" in that they are more likely to be stolen, because they are concealable, removable, available, valuable, enjoyable, and disposable (Clarke 1999). SCP measures can be implemented to change these product features. Prevention can start at the designing process, in which products are 
designed with potential criminal threats in mind (Ekblom 2012). Several examples should help support this point. Internet fraud is a major problem and digital watermarking designed into the software (impenetrably coding computer information) can protect computers, online pages, or other potential targets of tampering and copying (Lester 2001). "Karrysafe" handbags are designed with a velcro opening which makes a lot of noise. If someone tries to open the handbag, the owner will hear it and be able to react (Ekblom 2012). The "Puma" folding bike, uses part of the frame as a locking device; if the lock is cut, the bike is useless (Ekblom 2012). Cellphone companies that monitor consistency of cell phone use over a day can lock down the phone remotely if severe changes occur in usage (Meredith 2001). These examples are demonstrative of the plethora of possibilities for designing out crime that can be done at the public and corporate level (Lester 2001). Manufacturers who improve security measures in their products could also see financial benefits, as their products may be more desirable if they are less likely to be stolen. A government entity can influence product design by providing design incentives, creating research possibilities or shaming those companies who do not adhere to preventative design by informing the public that their products are more likely to be targets (Ekblom 2012).

Although situational crime prevention is most widely implemented for property crime, rewards of expressive or violent crimes (such as excitement) can be situationally prevented as well (Smith and Clarke 2012). Cohen and Felson developed, in reference to their routine activities theory, another understanding of targets of predatory crime. VIVA stands for value, inertia, visibility and accessibility (1979). Victims of predatory crime, be it muggings, abuse, sexual assault or others, are targeted because they are identified by an offender, are perceived as valuable, are readily available, and unable to remove themselves from the situation (Cohen and Felson 1979). This is useful for understanding why particular targets are chosen over others, but does not provide detail into how to prevent these situations. Cornish (1994) offered an extension, with his concept "crime scripts." Crime scripts detail each of the steps of the criminal event from the time of day that a particular predatory crime happens, to the particular actors, to the tools used. Events are sequential and in the commission of a crime, one event must precede another criminal event for the commission to be successful (Cornish 1994). This can range from planning the event, arriving at a particular place, looking for a potential victim, meeting a potential victim, ensuring lack of guardianship, approaching the victim, attacking the victim, continuing to attack them if they do not resist, realizing a particular reward (money, sex, etc.), and leaving the event (Cornish 1994). All of these situational stages can be subject to prevention when viewed as a series of sequential steps (Smith and Clarke 2012). Rather than attempting to change the individuals who may engage in predatory crimes, through SCP, one can alter criminogenic situations or places so the opportunities to commit crime are significantly reduced.

Thus, implementing SCP suggests the requirement for a new way of thinking about crime prevention at the national level in Canada. Since NCPC determines much of the financial support for crime prevention, it acts as a guiding body for most community-level implementation. The federal government in Canada also has jurisdiction over manufacturing changes that improve security. For example, NCPC 
might force the blacklisting of stolen phones at the national level, but provide financial support and guidance for environmental design to prevent crime at the local level. As previously discussed, several Canadian municipalities and provinces have already demonstrated leadership in integrated crime-prevention approaches and should be supported by the national framework (for example see: REACH Edmonton Council for Safe Communities: Building Partnerships to Reduce Crime in Saskatchewan; TANDEM Montreal; Waterloo Region Crime-prevention Council, etc.) By supporting a multidimensional approach to crime prevention, NCPC will maintain a strong framework for research on the most effective methods of crime prevention and use that knowledge to fund local crime-specific issues throughout Canada.

\section{Conclusion}

This paper proposed an important way in which the current model of crime prevention in Canada can be improved. There appears to be little if any formal effort to introduce situational crime prevention within Canada's national crime-prevention programme. A recent evaluation of NCPC recommended more extensive use of SCP, but does not appear to have resulted in any moves towards that end. This is despite integrated approaches towards crime prevention taking place in municipalities across the country and in parallel national crime-prevention bodies elsewhere, including the Home Office in the UK and the Australian Institute of Criminology. For the NCPC to support what is effective for preventing crime in Canada, the evidence suggests SCP should be considered a complementary strategy as it addresses specific crime types. Safe communities are those which combine several crime-prevention approaches that are locally based and crime specific (Linden 2007; Saville 2009). Incorporating situational crime prevention into the national strategy we suggest, will not only improve the safety and security of Canadians, but ensure the continued relevance of NCPC as a national crime-prevention body.

\section{References}

Allen, M. 2016. Police reported crime statistics in Canada, 2015. Statistics Canada. http://www.statcan. gc.ca/pub/85-002-x/2016001/article/14642-eng.htm.

Andresen, M.A. 2009. Crime specialization across the Canadian provinces. Canadian Journal of Criminology and Criminal Justice 51 (1): 31-53.

Andresen, M.A., and N. Malleson. 2011. Testing the stability of crime patterns: implications for theory and policy. Journal of Research in Crime and Delinquency 48 (1): 58-82.

Augimeri, L., D. Farrington, C. Koegl, and D. Day. 2007. The SNAP ${ }^{\mathrm{TM}}$ under 12 outreach project: effects of a community-based program for children with conduct problems. Journal of Child and Family Studies 16: 799-807.

Braga, A.A., D.M. Kennedy, E.J. Waring, and A.M. Piehl. 2001. Problem-oriented policing, deterrence, and youth violence: An evaluation of Boston's operation ceasefire. Journal of Research in Crime and Delinquency 38 (3): 195-225. 
Braga, A. 2005. Hot spots policing and crime prevention: A systematic review of randomized controlled trials. Journal of Experimental Criminology 1 (3): 317-342.

Brantingham, P.L., P.J. Brantingham, and W. Taylor. 2005. Situational crime prevention as a key component in embedded crime prevention. Canadian Journal of Criminology and Criminal Justice 47 (2): 271-292.

Canadian Municipal Network for Crime Prevention. 2016. Action briefs: Why invest in crime prevention in municipalities. CMNCP. www.safercities.ca.

Carleton, R., P.L. Brantingham, and P.J. Brantingham. 2014. Crime Specialization in Rural British Columbia, Canada. Canadian Journal of Criminology and Criminal Justice/La Revue Canadienne de Criminologie et de Justice Pénale 56 (5): 595-622.

Casavant, L. 2010. The general social survey: A way to track unreported crime. Hillnote No. 2010-69-E. Ottawa: Library of Parliament Research Publications.

CBC News. 2010. Counting crime in Canada: A closer look at the numbers. CBC News. http://www.cbc. ca/news/canada/counting-crime-in-canada-1.939285.

Centre for Addiction and Mental Health. 2015. The fourth R. Centre for Addiction and Mental Health. https://youthrelationships.org/.

Competition Bureau Canada. 2012. Canadian Anti-Fraud Centre Criminal Intelligence Analytical UnitAnnual statistical report 2012. https://www.antifraudcentre-centreantifraude.ca/english/documents/ Annual\%202012\%20CAFC.pdf.

Clarke, R.V. 1997. Situational crime prevention: Successful case studies, 2nd ed. Guiderland, NY: Criminal Justice Press.

Clarke, R.V. 1999. Hot products: Understanding, anticipating and reducing demand for stolen goods. Police Research Series, Paper 112. London: Home Office.

Clarke, R., and D. Cornish. 1985. Modelling offenders' decisions: A framework for research and Policy. In Crime and justice: An annual review of research, vol. 6, ed. T. Michael, and N. Morris, 147-185. Chicago, IL: The University of Chicago Press.

Cornish, D.B. 1994. The procedural analysis of offending and its relevance for situational prevention. In Crime prevention studies, vol. 2, ed. R.V. Clarke. Monsey, NY: Criminal Justice Press.

Copes, H. 2003. Street life and the rewards of auto-theft. Deviant Behavior 24 (4): 309-332.

Cornish, D.B., and R.V. Clarke. 2003. Opportunities, precipitators and criminal decisions: A reply to Wortley's critique of situational crime prevention. In Theory and practice in situational crime prevention, vol. 16, ed. M.J. Smith, and D.B. Cornish. Monsey, NY: Criminal Justice Press.

Cohen, L., and M. Felson. 1979. Social change and crime rate trends: A routine activity approach. American Sociological Review 44 (4): 588-608.

Clarke, M.J., and R.V. Smith. 2012. Situational crime prevention: Classifying techniques using 'good enough' theory. In Oxford handbook of crime prevention, ed. B.C. Welsh, and D.P. Farrington. New York, NY: Oxford University Press.

Clarke, R. V., and Mayhew, P. 1988. The British gas suicide story and its criminological implications. Crime and justice 10: 79-116.

Cohen, M.A. 2000. Measuring the costs and benefits of crime and justice. In Measurement and analysis of crime and justice, Criminal Justice, 2000, vol. 4, ed. D. Duffee. National Institute of Justice: Rockville, MD.

Curman, A.S.N., M.A. Andresen, and P.J. Brantingham. 2015. Crime and place: A longitudinal examination of street segment patterns in Vancouver. BC. Journal of Quantitative Criminology 31 (1): $127-147$.

Ekblom, P. 2012. The private sector and designing products against crime. In Oxford handbook of crime prevention, ed. B.C. Welsh, and D.P. Farrington. New York: Oxford University Press.

Farrell, G., N. Tilley, A. Tseloni, and J. Mailley. 2011. The crime drop and the security hypothesis. Journal of Research in Crime and Delinquency 48 (2): 147-175.

Farrell, G., and Pease, K. 2007. Preventing repeat residential burglary victimization. In: Preventing crime, 161-176. New York: Springer.

Farrell, G., and P.J. Brantingham. 2013. The crime drop and the general social survey. Canadian Public Policy 34 (4): 559-580.

Farrell, G., N. Tilley, and A. Tseloni. 2014. 'Why the crime drop. In Why crime rates fall and why they don't, Crime and Justice: A review of research, vol. 43, ed. M. Tonry, 421-490. Chicago: University of Chicago Press.

Farrington, D.P. 2000. Explaining and preventing crime: The globalization of knowledge-The American Society of Criminology Presidential Address. Criminology 38 (1): 1-24. 
Government of Canada. 2013. Demographic overview of aboriginal peoples in Canada and aboriginal peoples in federal corrections. Correctional Service of Canada http://www.csc-scc.gc.ca/aboriginal/ 002003-1008-eng.shtml.

Government of Canada. 2015. Aboriginal peoples as victims of crime. National Victims of Crime Awareness Week. http://www.victimsweek.gc.ca/res/r57.html.

Hastings, R. 2005. Perspectives on crime prevention: Issues and challenges. Canadian Journal of Criminology and Criminal Justice 47 (2): 209-220.

Hayes, R., D. Downs, and R. Blackwood. 2011. Anti-theft procedures and fixtures: A randomized controlled trial of two situational crime prevention measures. Journal of Experimental Criminology 8 (1): 1-15.

Hodgkinson, T., M.A. Andresen, and G. Farrell. 2016. The decline and locational shift of automotive theft: A local level analysis. Journal of Criminal Justice. 44: 49-57.

Homel, P. 2006. Joining up the pieces: What central agencies need to do to support effective local crime prevention. In Putting theory to work: Implementing situational prevention and problem oriented policing, ed. J. Knutsson, and R.V. Clarke, 111-138. Monsey, NY: Willow Tree Press.

Homel, R. 2005. Developmental crime prevention. In Handbook of crime prevention and community safety, ed. N. Tilley, 71-106. Oxfordshire: Willan.

Janhevich, D., Johnson, H., Vezina, C., \& Fraser, J. 2008. Making cities safer: Canadian strategies and practices. Institute for the Prevention of Crime. No. 2. www.prevention-crime.ca.

Karmen, A. 2000. New York murder mystery: The true story behind the crime crash of the 1990s. New York: NYU Press.

Knepper, P. 2009. How situational crime prevention contributes to social welfare. Liverpool Law Review 30 (1): 57-75.

Knepper, P. 2012. An international crime decline: Lessons for social welfare crime policy. Social policy and administration 46 (4): 359-376.

Lester, A. 2001. Crime reduction through issues product design. Trends and Issues in Crime and Criminal Justice 206: 1-6.

Linden, R. 2007. Situational crime prevention: Its role in comprehensive initiatives. IPC Review 1: 139-159.

Linden, R., and R. Chaturvedi. 2005. The need for comprehensive crime prevention planning: The case of motor vehicle theft. Canadian Journal of Criminology and Criminal Justice 47 (2): 251-270.

Leonard, L., G. Rosario, C. Scott, and J. Bressan. 2005. Building safer communities: Lessons learned from Canada's national strategy. Canadian Journal of Criminology and Criminal Justice 47 (2): 233-250.

Levitt, S.D. 2004. Understanding why crime fell in the 1990s: Four factors that explain the decline and six that do not. Journal of Economic Perspectives 18 (1): 163-190.

Lieberson, S. 1992. Einstein, Renoir and Greeley: Some thoughts about evidence in sociology: 1991 presidential address. American Sociological Review 57: 1-15.

Mailley, J., R. Garcia, S. Whitehead, and G. Farrell. 2008. Phone theft index. Security Journal 21 (3): 212-227.

Manitoba Justice. 2009. The Winnipeg auto theft suppression strategy. http://www.popcenter.org/library/ awards/goldstein/2009/09-42(F).pdf.

Mayhew, P.M., R.V.G. Clarke, A. Sturman and M. Hough. 1976. Crime as Opportunity. Home Office Research Study No.43. London: HMSO.

Meredith, H. (2001, February 9). Sentinels help guard against mobile phone fraud. The Australian Financial Review, pp. 28.

National Institute of Justice. 2016. Crimesolutions.gov. Office of Justice Programs. www.crimesolutions. gov.

Ouimet, M. 2002. Explaining the Canadian and American crime 'drop' in the 1990s. Canadian Journal of Criminology 44 (33): 33-50.

Pearce, F., and S. Tombs. 1998. Toxic capitalism: Corporate crime and the chemical industry. Surrey: Ashgate.

Perreault, S. 2015. Criminal victimization in Canada, 2014. Statistics Canada. http://www.statcan.gc.ca/ pub/85-002-x/2015001/article/14241-eng.htm\#a8.

Public Safety Canada. 2007a. 2007-2008 Interim evaluation of the renewed national crime prevention strategy. http:/www.publicsafety.gc.ca/cnt/rsrcs/pblctns/archive-vltn-rnw-ntnl-crm-2007-08/ archive-ncps-snpc-eng.pdf. 
Public Safety Canada. 2007b. A blueprint for effective crime prevention. http://publications.gc.ca/site/ eng/312623/publication.html.

Public Safety Canada. 2009. Supporting the successful implementation of the national crime prevention strategy. http://www.publicsafety.gc.ca/cnt/rsrcs/pblctns/spprtng-mplmtn/index-eng.aspx\#t1.

Public Safety Canada. 2013. 2012-2013 Evaluation of the crime prevention program. http://www. publicsafety.gc.ca/cnt/rsrcs/pblctns/2013-vltn-crm-prvntn-prgrm/index-eng.aspx\#a14.

Public Safety Canada. 2016a. Report on plans and priorities 2016-2017. https://www.publicsafety.gc.ca/ $\mathrm{cnt} /$ rsrcs/pblctns/rprt-plns-prrts-2016-17/index-en.aspx\#s1c.

Public Safety Canada, 2016b. Summary of the Atlantic youth inclusion program. Evaluation. https:// www.publicsafety.gc.ca/cnt/rsrcs/pblctns/2015-s047/2015-s047-en.pdf.

Russell, H., and Taylor, N. 2014. New directions in community safety: Consolidating lessons learned about risk and collaboration. Ontario Association of Chiefs of Police. http://www.oacp.on.ca/ Userfiles/StandingCommittees/CommunityPolicing/ResourceDocs/1\%20-\%20Framework\%20for\% 20Community\%20Safety\%20PlanningJune20.pdf.

Sacco, V., and L. Kennedy. 2011. The criminal event: An introduction to criminology in Canada, 5 th ed. Toronto, ON: Nelson Education Ltd.

Saville, G. 2009. SafeGrowth: Moving forward in neighbourhood development. Built Environment 35 (3): 386-402.

Sampson, R.J., and W.B. Groves. 1989. Community structure and crime: Testing social-disorganization theory. American Journal of Sociology 94 (4): 774-802.

Sampson, R.J., and J.H. Laub. 2003. Shared beginnings, divergent lives: Boys to age. Cambridge, MA: Harvard University Press.

Sansfacon, D., and I. Waller. 2001. Recent evolution of governmental crime prevention strategies and implications for evaluation and economic analysis. In Costs and benefits of preventing crime, ed. B.C. Welsh, D.P. Farrington, and L.W. Sherman. Boulder, CO: Westview Press.

Sansfacon, D., and L. Leonard. 2012. Blueprint for effective crime prevention in Canada: The national crime prevention strategy. IPC Review 3: 75-79.

Sherman, L., Gottfredson, D., Mackensie, D. Eck, J., Reuter, P. \& Bushway, S. 1998. Preventing crime: What works, what doesn't, what's promising. National Institute of Justice Research in Brief. Washington, DC: Office of Justice Programs, U.S. Department of Justice. http://www.ncjrs.org/ works/.

Snider, L. 1993. Bad business: Corporate crime in Canada. Scarborough, ON: Nelson.

Statistics Canada. 2013. Police reported crime statistics, 2013. Government of Canada. http://www. statcan.gc.ca/daily-quotidien/140723/dq140723b-eng.htm.

Symantec. 2013. 2013 Norton Report. http://www.symantec.com/content/en/us/about/presskits/b-nortonreport-2013.en_ca.pdf.

Tilley, N. 2009. Crime prevention. Portland, OR: Willan Publishing.

Tilley, N., G. Farrell, and R.V. Clarke. 2015. Target suitability and the crime drop. In Routine activities and the criminal act, ed. M. Andresen, and G. Farrell, 59-76. London: Palgrave Macmillan.

Tonry, M. 2004. Why aren't German penal policies harsher and imprisonment rates higher? German Law Review 5: 1187-1206.

Tombs, S. 2013. Corporate crime. In Criminology, 3rd ed, ed. C. Hale, K. Hayward, A. Wahidin, and E. Wincup, 227-246. Oxford: Oxford University Press.

United Nations Office on Drugs and Crime. 2002. Action to promote effective crime prevention. Retrieved from the UNODC website: http://www.unodc.org/documents/justice-and-prisonreform/ crimeprevention/resolution_2002-13.pdf.

United Nations Office on Drugs and Crime. 2010. Handbook on the crime prevention guidelines: Making them work. Criminal Justice Handbook Series. https://www.unodc.org/pdf/criminal_justice/ Handbook_on_Crime_Prevention_Guidelines_-_Making_them_work.pdf.

van Dijk, J., A. Tsleoni, and G. Farrell. 2012. The international crime drop: New directions in research. Basingstoke: Palgrave and McMillan.

Vanderschueren, F. 1998. Towards safer cities. UNCHS Habitat Debate 4 (1): 68-79.

Wallace, M., J. Turner, A. Matarrazo, and C. Babyak. 2009. Measuring crime in Canada: Introducing the crime severity index and improvements to the uniform crime reporting survey. Ottawa: Statistics Canada.

Waller, I. 2008. Less law, more order: The truth about reducing crime. Hamilton, ON: Manor House Publishing. 
Waller, I. 2013. Smarter crime control: A guide to a safer future for citizens, communities and politicians. Landham, MD: Rowman \& Littlefield.

Welsh, B., and D. Farrington. 2012. The oxford handbook of crime prevention. New York, NY: Oxford University Press Inc.

World Health Organization. 2010. Violence prevention: The evidence. Centre for public health. http:// apps.who.int/iris/bitstream/10665/77936/1/9789241500845_eng.pdf?ua=1.

Wotherspoon, T., and B. Schissel. 2001. The business of placing Canadian children and youth 'at-risk'. Canadian Journal of Education 26 (3): 321-339. 